\title{
Granulomatous pyelitis associated with urinary obstruction: a comprehensive clinicopathologic study
}

\author{
Gulfiliz Gonlusen ${ }^{1,2}$, Anh Truong ${ }^{3}$, Steven S Shen ${ }^{1,4}$, Horacio E Adrogue ${ }^{3}$, \\ Venkat Ramanathan ${ }^{3}$ and Luan D Truong ${ }^{1,2,3,4}$
}

${ }^{1}$ Department of Pathology, The Methodist Hospital, Houston, TX, USA; ${ }^{2}$ Department of Pathology, Baylor College of Medicine, Houston, TX, USA; ${ }^{3}$ Department of Medicine, Renal Section, Baylor College of Medicine, Houston, TX, USA and ${ }^{4}$ Department of Pathology, Weill Medical College of Cornell University, New York, $N Y, U S A$

\begin{abstract}
Urinary obstruction is rarely associated with a distinct granulomatous inflammation, which involves the pyelocalyceal system and closely simulates infectious conditions including tuberculosis. Its clinicopathologic features, however, have not been adequately studied since there are only seven isolated reported cases. In a comprehensive study of $\mathbf{1 1 2}$ kidney specimens with urinary obstruction, we identified five cases of granulomatous pyelitis. The features of these cases were detailed and compared with the previously reported cases. Among the five identified subjects, three patients had history of urolithiasis and two had ureteral stenosis and all had stent placement $\mathbf{7}$ weeks to 12 years before nephrectomy for relief of the unilateral urinary obstruction. The age distribution was between 38 and 81 years. Two had end-stage renal disease or chronic renal failure. The pyelocaliceal system showed frank hydronephrosis (1 case) or partial dilatation (4 cases) and contained cheesy and gritty material in its lumen. Each case showed severe granulomatous inflammation, which was limited to the pelvic wall and closely associated with calcified debris, necrotic inflammatory cells, and material consistent with Tamm-Horsfall protein. The kidney showed chronic tubulointerstitial nephritis but without granulomas. Cultures of urine, blood, and the renal pelvic content, and special stains of tissue sections did not show fungi or mycobacteria in any case. Many of these features were also observed in previously reported cases. Granulomatous pyelitis is a rare but distinct cliniocopathologic entity characterized by severe noninfectious granulomatous inflammation limited to the renal pelvis, which is uniformely asociated with urinary obstruction and pyelocalyceal dilatation and may develop in response to accumulated calcified material in the renal pelvis. Awareness of this entity and its characteristic clinicopathologic features also helps eliminate an infectious etiology with obvious treatment and prognostic implications.

Modern Pathology (2006) 19, 1130-1138. doi:10.1038/modpathol.3800638; published online 19 May 2006
\end{abstract}

Keywords: urinary obstruction; granulomatous inflammation of kidney; granulomatous pyelitis; lithiasis; mycobacteria; fungus

Chronic urinary obstruction causes characteristic changes of the pyelocalyceal system and the kidney. The pyelocalyceal system shows dilatation, intact urothelium with reactive atypia, active inflammation of its wall, and thickening of its muscularis. The kidney changes include tubular atrophy, interstitial fibrosis, and active interstitial inflammation, but the glomeruli and blood vessels are intact. The

Correspondence: Dr LD Truong, MD, Department of Pathology, MS 205, The Methodist Hospital, 6565 Fannin Street, Houston, TX 77030, USA.

E-mail: ltruong@tmh.tmc.edu

Received 22 February 2006; revised and accepted 24 April 2006; published online 19 May 2006 end result is variable loss of renal parenchyma. These changes are often so characteristic that a diagnosis of obstructive uropathy can be readily made in a nephrectomy specimen without knowledge of the clinical condition of urinary obstruction. ${ }^{1}$

Urinary obstruction, however, rarely does not induce the characteristic changes described above, but is associated with a distinct granulomatous inflammation, which involves the pyelocalyceal system and closely simulates infectious conditions, for which the term pseudotuberculous chronic pyelonephritis was coined. ${ }^{2}$ In spite of the obvious diagnostic and therapeutic implications of this condition, its clinicopathologic features have not 
been adequately studied since only seven isolated cases were previously reported. ${ }^{2-7}$

We wish to describe five new cases and compare them with previously reported cases to comprehensively assess the morphologic spectrum, pathogenesis, and diagnostic implications of this entity.

\section{Materials and methods}

Cases of nephrectomy with chronic urinary obstruction of any cause including urinary tract neoplasms during an 11-year-period from 1994 to 2005 were reviewed to identify those with granulomatous pyelitis. Among the 112 such cases, five cases of GP were identified. Selected tissue sections of each case of GP were subjected to histochemical stains including Masson's trichome, periodic acid-Schiff, von Kossa, alizarin red, Gram stain, acid fast bacilli stain, and Gomori's methenamine silver (GMS) stain for fungi; and to immunostain for Tamm-Horsfall protein (Rabbit polyclonal antibody, Biomedia (Raritan, CA), dilution 1:200). The clinical features and follow-up information, with special attention to those that may explained the granulomatous inflammation, were obtained from the medical records.

\section{Results}

\section{Clinical Features}

The clinical features are reported below and summarized in Table 1.

\section{Case 1}

A 51-year-old woman presented with right flank pain. Renal imaging study showed right hydronephrosis and right ureteral stenosis $4 \mathrm{~cm}$ from the bladder. The left kidney, left pyelocalyceal system, left ureter, and urinary bladder were normal. Her past medical history was significant for 'tuberculosis of the right elbow' when she was 9 years old and repeated urinary tract infection. She was treated with right urinary stent twice and antibiotics for tuberculosis including INH and rifampin for 18 months before this admission. Renal imaging at this time showed an intact stent in the right renal pelvis, and a cystic area in the lower pole of the right kidney associated with calcification, but there was no hydronephrosis. The left urinary tract remained normal. Currently, there were no clinical, bacteriologic or imaging features of active tuberculosis Laboratory studies during this admission showed WBC $8.6 \times 10^{3}$ cells/c.mm, Hgb $12.2 \mathrm{~g} / \mathrm{dl}$, Hct $34.6 \%$, platelet $256 \times 10^{3}$ cells/c.mm, serum sodium $140 \mathrm{mEq} / \mathrm{l}$, potassium $3.9 \mathrm{mEq} / \mathrm{l}$, chloride $105 \mathrm{mEq} /$ l, glucose $87 \mathrm{mg} / \mathrm{dl}$, calcium $8.9 \mathrm{mg} / \mathrm{dl}$, total serum protein $7.5 \mathrm{~g} / \mathrm{dl}$, serum albumin $4.7 \mathrm{~g} / \mathrm{dl}$, BUN $11 \mathrm{mg} / \mathrm{dl}$, and serum creatinine $0.9 \mathrm{mg} / \mathrm{dl}$. Repeated urine cultures were negative for fungi and bacteria, including mycobacteria. Right nephrectomy was performed. The patient was alive and well without features of tuberculosis at most recent follow-up.

Case 2

A 38-year-old man presented with severe right flank pain. His past medical history was significant for end-stage renal disease of unknown etiology, requiring maintenance hemodialysis for the past 6 years, partial right nephrectomy at the age of 28 years for hydronephrosis due to lithiasis, and placement of right ureteral stent at the age of 30 years for persistent urinary obstruction. During the current admission, the laboratory studies showed WBC $16.3 \times 10^{3}$ cells/c.mm, Hgb $7.1 \mathrm{~g} / \mathrm{dl}$, Hct $22.3 \%$, platelet $705 \times 10^{3}$ cells/c.mm, sodium $143 \mathrm{mEq} / \mathrm{l}$, potassium $4.8 \mathrm{mEq} / \mathrm{l}$, chloride $108 \mathrm{mEq} / \mathrm{L}$, serum creatinine $7.1 \mathrm{mg} / \mathrm{dl}$, glucose $128 \mathrm{mg} / \mathrm{dl}$, calcium $9.7 \mathrm{mg} / \mathrm{dl}$, and a serum parathyroid hormone $91 \mathrm{pg} /$ dl (normal 13-65). There was cutaneous induration in the right arm and right gluteal area, the biopsies of which showed calcinosis cutis. A plain abdominal X-ray showed an intact urinary stent in the right ureter and multifocal calcification in the right kidney, consistent with lithiasis. Urine and blood cultures were negative for bacteria and fungi. He was initially treated with replacement of the ureteral stent, but due to progressive pain right nephrectomy was performed the next day.

Case 3

An 81-year-old woman presented with progressive right flank pain, chills, fever, and sweating. She has required hemodialysis for the past 3 months for diabetic end-stage renal disease. Twelve years ago, she underwent radical cystectomy with ileal conduit for bladder cancer, which was later complicated by recurrent right ureteral obstruction requiring multiple stent placements. Physical examination showed a temperature of $102.6^{\circ} \mathrm{F}$, blood pressure $130 / 70 \mathrm{mmHg}$, pulse rate $84 / \mathrm{min}$ and respiratory rate of $14 / \mathrm{min}$. There was a right nephrostomy tube in place. Laboratory studies showed WBC $9.8 \times 10^{3}$ cells/c.mm, Hgb $11.7 \mathrm{~g} / \mathrm{dl}$, Hct $37.2 \%$, platelets $255 \times 10^{3}$ cells/c.mm, serum sodium $135 \mathrm{mEq} / \mathrm{l}$, potassium $3.5 \mathrm{mEq} / \mathrm{l}$, chloride $95 \mathrm{mEq} / \mathrm{l}$, glucose $130 \mathrm{mg} / \mathrm{dl}$, calcium $7.7 \mathrm{mg} / \mathrm{dl}$, phosphorus $3.1 \mathrm{mg} /$ $\mathrm{dl}$, creatinine $5.7 \mathrm{mg} / \mathrm{dl}$, total serum protein $6.8 \mathrm{~g} / \mathrm{dl}$, serum albumin $3.2 \mathrm{~g} / \mathrm{dl}$, and serum uric acid $5.5 \mathrm{mg} /$ dl. Urine analysis showed $2+$ protein, many WBC's and Gram-positive cocci in urine culture, but no fungi or mycobacteria. Blood cultures were negative. The patient underwent a right nephrectomy.

Case 4

A 50-year-old man with a past medical history of renal lithiasis 8 years ago presented with periodic abdominal pain in the past several months. Laboratory studies showed Hgb $10.3 \mathrm{~g} / \mathrm{dl}$ with normal WBC and platelet counts (WBC $10.4 \times 10^{3}$ cells/c.mm platelets $284 \times 10^{3}$ cells/c.mm), sodium $144 \mathrm{mEq} / \mathrm{l}$, potassium $4.4 \mathrm{mEq} / \mathrm{l}$, chloride $105 \mathrm{mEq} / \mathrm{l}$, creatinine 
Table 1 Clinical and pathologic features of the current and reported cases of granulomatous pyelitis

\begin{tabular}{|c|c|c|c|c|c|c|c|c|c|c|c|}
\hline \multirow[t]{2}{*}{ Case no. } & \multirow[t]{2}{*}{ Year } & \multirow[t]{2}{*}{ Authors } & \multirow{2}{*}{$\begin{array}{l}\text { Age } \\
\text { Yrs }\end{array}$} & \multirow[t]{2}{*}{ Sex } & \multirow[t]{2}{*}{ Associated conditions } & \multirow[t]{2}{*}{ Renal imaging } & \multicolumn{4}{|c|}{ Organisms } & \multirow{2}{*}{$\begin{array}{l}\text { Stones i } \\
\text { specime }\end{array}$} \\
\hline & & & & & & & Urine culture & $\begin{array}{l}\text { Blood } \\
\text { culture }\end{array}$ & $\begin{array}{l}\text { Renal pelvic } \\
\text { culture }\end{array}$ & $\begin{array}{l}\text { Renal pelvic } \\
\text { tissue stains }\end{array}$ & \\
\hline \multicolumn{12}{|c|}{ Current cases } \\
\hline 1 & & & 51 & $\mathrm{~F}$ & $\begin{array}{l}\text { Rt ureteral stenosis. } \\
\text { Hx of remote cutaneous } \\
\text { tuberculosis }\end{array}$ & $\begin{array}{l}\text { Rt: Atrophic, no } \\
\text { hydronephosis (Hx of stent) } \\
\text { Lt: Normal }\end{array}$ & $\begin{array}{l}\text { Negative for } \\
\text { bacteria and } \\
\text { fungi }\end{array}$ & $\begin{array}{l}\text { Negative for } \\
\text { bacteria and } \\
\text { fungi }\end{array}$ & $\begin{array}{l}\text { Cultures negative } \\
\text { for fungus } \\
\text { and AFB }\end{array}$ & $\begin{array}{l}\text { Negative Gram, } \\
\text { AFB, and } \\
\text { GMS stains }\end{array}$ & No \\
\hline 2 & & & 38 & $\mathrm{M}$ & $\begin{array}{l}\text { Rt renal lithiasis } \\
\text { Idiopathic end-stage } \\
\text { renal disease } \\
\text { Hypercalcemia } \\
\text { Cutaneous calcinosis } \\
\text { Hyperparathyroidism }\end{array}$ & $\begin{array}{l}\text { Rt: Atrophic, no } \\
\text { hydronephosis } \\
\text { (Hx of stent) } \\
\text { Lt: Normal }\end{array}$ & $\begin{array}{l}\text { Negative for } \\
\text { bacteria } \\
\text { and fungi }\end{array}$ & $\begin{array}{l}\text { Negative for } \\
\text { bacteria and } \\
\text { fungi }\end{array}$ & $\begin{array}{l}\text { Cultures negative } \\
\text { for anaerobic, } \\
\text { fungus } \\
\text { and AFB }\end{array}$ & $\begin{array}{l}\text { Negative Gram, } \\
\text { AFB, and } \\
\text { GMS stains }\end{array}$ & Yes \\
\hline 3 & & & 81 & $\mathrm{~F}$ & $\begin{array}{l}\text { Recurrent obstruction } \\
\text { of the Rt ureter } \\
\text { Radical cystectomy } \\
\text { for bladder cancer } \\
\text { with ileal conduit } \\
\text { Diabetic end-stage } \\
\text { kidney disease } \\
\text { Acute pyelonephritis }\end{array}$ & $\begin{array}{l}\text { Rt: Atrophic, no } \\
\text { hydronephosis (Hx of stent) } \\
\text { Lt: Normal }\end{array}$ & $\begin{array}{l}\text { Negative for } \\
\text { bacteria } \\
\text { and fungi }\end{array}$ & $\begin{array}{l}\text { Negative for } \\
\text { bacteria and } \\
\text { fungi }\end{array}$ & Not done & $\begin{array}{l}\text { Negative Gram, } \\
\text { AFB, and } \\
\text { GMS stains }\end{array}$ & No \\
\hline 4 & & & 50 & $\mathrm{M}$ & Lt renal lithiasis & $\begin{array}{l}\text { Rt: Normal (Hx of stent) } \\
\text { Lt: Atrophic, } \\
\text { hydronephrosis }\end{array}$ & $\begin{array}{l}\text { Negative for } \\
\text { bacteria and } \\
\text { fungi }\end{array}$ & $\begin{array}{l}\text { Negative for } \\
\text { bacteria and } \\
\text { fungi }\end{array}$ & $\begin{array}{l}\text { Cultures negative } \\
\text { for anaerobic } \\
\text { bacteria, fungus, } \\
\text { and AFB }\end{array}$ & $\begin{array}{l}\text { Negative Gram, } \\
\text { AFB, and } \\
\text { GMS stains }\end{array}$ & Yes \\
\hline 5 & & & 55 & $\mathrm{~F}$ & $\begin{array}{l}\text { Recurent lithiasis } \\
\text { and infection of Lt } \\
\text { kidney } \times 8 \text { years }\end{array}$ & $\begin{array}{l}\text { Rt: Atrophic, } \\
\text { no hydronephosis } \\
\text { (Hx of stent and lithotripsy) } \\
\text { Lt: Normal }\end{array}$ & $\begin{array}{l}\text { Negative for } \\
\text { bacteria } \\
\text { and fungi }\end{array}$ & $\begin{array}{l}\text { Negative for } \\
\text { bacteria and } \\
\text { fungi }\end{array}$ & Not done & $\begin{array}{l}\text { Negative Gram, } \\
\text { AFB, and } \\
\text { GMS stains }\end{array}$ & Yes \\
\hline \multicolumn{12}{|c|}{ Reported cases } \\
\hline 1 & 92 & Hoorens $^{2}$ & 40 & M & $\begin{array}{l}\text { Bilateral renal lithiasis } \\
\text { since } 13 \text { years old and } \\
\text { recurrent hydronephrosis }\end{array}$ & $\begin{array}{l}\text { Rt: Hydronephrosis } \\
\text { Lt: Atrophic }\end{array}$ & $\begin{array}{l}\text { Negative for } \\
\text { Mycobacteria }\end{array}$ & Not mentioned & Not mentioned & $\begin{array}{l}\text { Negative Gram, } \\
\text { AFB, and } \\
\text { GMS stains }\end{array}$ & Yes \\
\hline 2 & 94 & $\begin{array}{l}\text { Valerdis } \\
\text { casasola }^{3}\end{array}$ & 67 & $\mathrm{~F}$ & Renal lithiasis & $\begin{array}{l}\text { Rt: Normal } \\
\text { Lt: Staghorn stones, } \\
\text { parenchymal abcess }\end{array}$ & $\begin{array}{l}\text { Negative for } \\
\text { Mycobacteria }\end{array}$ & Not mentioned & $\begin{array}{l}\text { Cultures negative } \\
\text { for Mycobacteria }\end{array}$ & $\begin{array}{l}\text { Negative AFB } \\
\text { and GMS } \\
\text { stains }\end{array}$ & Yes \\
\hline 3 & 98 & Bouzourene $^{4}$ & 30 & $\mathrm{~F}$ & $\begin{array}{l}\text { Lt renal lithiasis and } \\
\text { hydronephrosis } \\
\text { for } 3 \text { years treated } \\
\text { by lithotrypsy }\end{array}$ & $\begin{array}{l}\text { Lt: Atrophic with } \\
\text { staghorn stones, } \\
\text { hydronephosis } \\
\text { Rt: Not described }\end{array}$ & Not mentioned & Not mentioned & $\begin{array}{l}\text { Cultures negative } \\
\text { for bacteria; PCR of } \\
\text { paraffin-embedded } \\
\text { tissue negative for } \\
\text { Mycobacteria }\end{array}$ & $\begin{array}{l}\text { Negative Gram, } \\
\text { AFB, and } \\
\text { GMS stains }\end{array}$ & Yes \\
\hline 4 & 99 & $\begin{array}{l}\text { Muldoon }{ }^{5} \\
\text { Case } 1\end{array}$ & 30 & $\mathrm{~F}$ & $\begin{array}{l}\text { Bilateral renal lithiasis } \\
\text { since infancy } \\
\text { Renal transplant from } \\
12-25 \text { years } \\
\text { Dialysis since } 25-27 \text { years }\end{array}$ & $\begin{array}{l}\text { Rt: Atrophic with } \\
\text { staghorn stones } \\
\text { Lt: Atrophic with } \\
\text { staghorn stones }\end{array}$ & $\begin{array}{l}\text { Positive for } \\
\text { E. coli and } \\
\text { Pseudomonas, } \\
\text { negative for } \\
\text { Mycobacteria }\end{array}$ & Not mentioned & Not mentioned & $\begin{array}{l}\text { Negative Gram, } \\
\text { AFB, and } \\
\text { GMS stains }\end{array}$ & Yes \\
\hline
\end{tabular}


$1.3 \mathrm{mg} / \mathrm{dl}$, and calcium $8.7 \mathrm{mg} / \mathrm{dl}$. Urine analysis showed moderate leukocytes. Urine and blood cultures were negative for fungi and bacteria including mycobacteria. Renal imaging showed left hydronephrosis secondary to stones involving the mid and lower pole portion of the renal pelvis and the mid portion of the ureter. The right kidney was unremarkable. A left ureteral stent was placed but produced no improvement and left nephrectomy was performed.

Case 5

A 55-year-old woman was admitted for right nephrectomy. She had recurrent lithiasis and infection of the right kidney in the past 8 years, which was treated with stent and lithotripsy. However, the affected kidney became atrophic and nephrectomy was recommended. During this admission, the laboratory studies showed WBC count of $12.96 \times 103$ cells/c.mm, Hgb $10.8 \mathrm{~g} / \mathrm{dl}$, Hct $31.2 \%$, platelets $153 \times 10^{3} \mathrm{cells} / \mathrm{c} . \mathrm{mm}$, serum sodium $138 \mathrm{mEq} / \mathrm{l}$, potassium $3.5 \mathrm{mEq} / \mathrm{l}$, chloride $106 \mathrm{mEq} /$ l, glucose $130 \mathrm{mg} / \mathrm{dl}$, calcium $8.2 \mathrm{mg} / \mathrm{dl}$, and creatinine $0.8 \mathrm{mg} / \mathrm{dl}$.

\section{Pathologic Findings}

\section{Gross}

The specimens included partial (Case 2) or total (other cases) nephrectomy specimens. There was obvious hydronephrosis in Case 4 , but diffuse or focal mild dilatation of the pyelocalyceal system was noted in other cases. Various amount of necrotic, cheesy, and gritty material was noted in the pelvic lumen in each case. The pelvic surface showed focal or diffuse granular areas, adjacent to those with smooth surface. The pelvic wall was focally or diffusely thickened. Dense fibrosis of the peripelvic soft tissue was noted in Case 4. Stones were found in renal pelvis and ureter in Case 2, ureter in Case 4, and renal pelvis in Case 5. The kidneys showed focally or diffuse cortical and medullary thinning. Involvement of the perirenal or peripelvic soft tissue or solid yellow areas was not observed in any case.

\section{Microscopic}

The renal pelvis showed granulomatous inflammation in each case (Figures 1 and 2). The granulomatous inflammation had a characteristic layering appearance (Figures 1a,c and 2) consisting of (1) a mixture of necrotic cellular debris, acute and chronic inflammatory cells, calcified material stained positive by both von Kossa and Alizarin red stains, and material with features consistent with Tamm-Horsfall protein (glassy, PAS + acellular material positively stained with antibody against this protein), which occupied the pelvic lumen (Figure 3a-c); (2) accumulation of macrophages, with or without associated multinucleated giant 

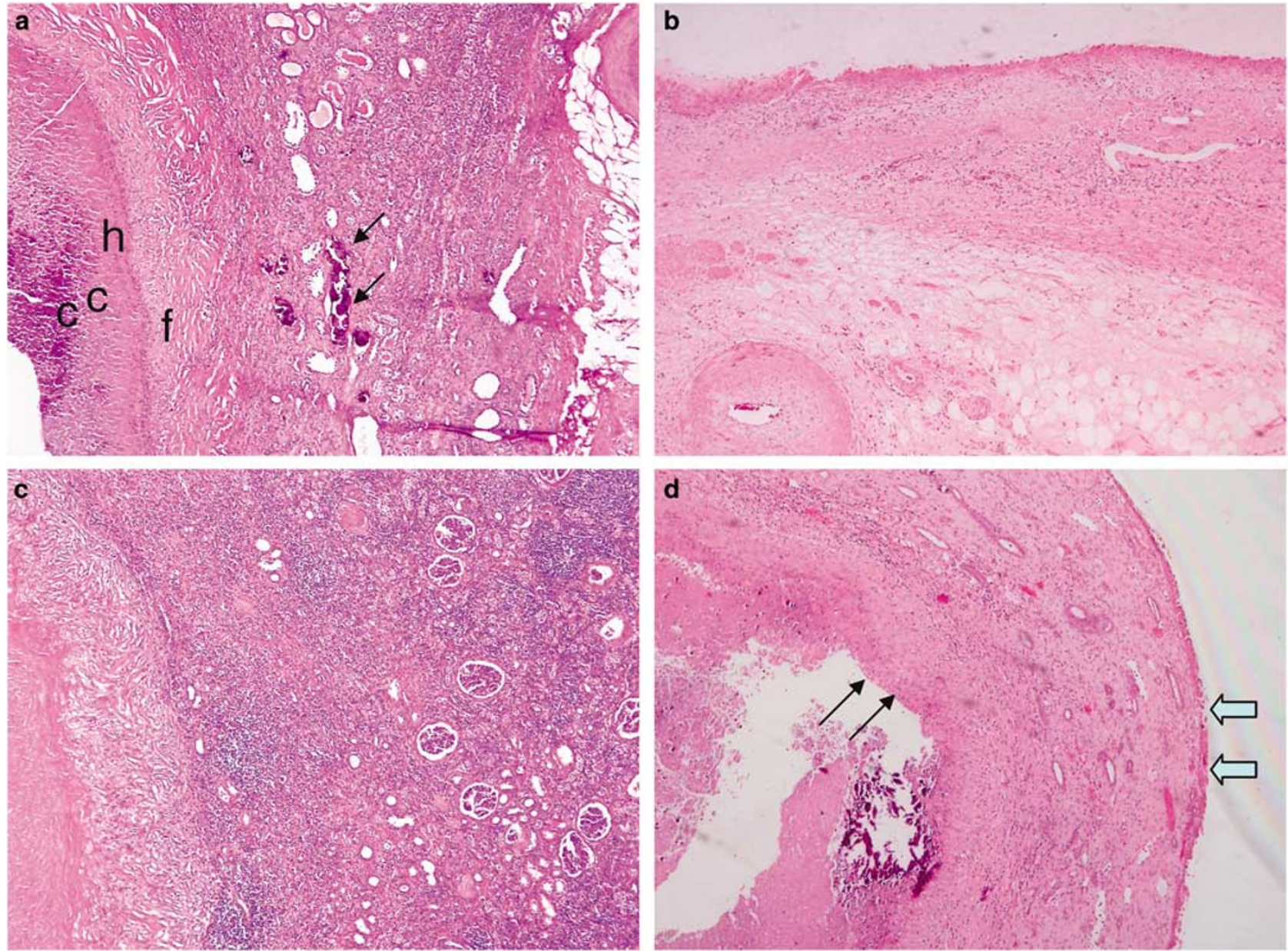

Figure 1 (a) Case 2: the granulomatous inflammation is limited to the renal pelvis and shows a characteristic layering including necrocalcified material (c), replacement of the urothelium by histiocytes (h), and fibro-inflammatory tissue (f). The renal tissue shows severe atrophy and focal calcification (arrows) without granulomatous inflammation. (b) Case 1: the granulomatous inflammation is limited to the pelvic wall (upper) without involvement of the peripelvic soft tissue (lower). Marked intimal thickening of a small artery, a nonspecific change, is noted. (c) Case 4: the granulomatous inflammation with the characteristic layering is limited to the renal pelvis (left). The kidney shows atrophic changes, without granulomatous inflammation (right). (d) Case 2: the granulomatous inflammation is focal with an affected area (thin arrows) adjacent to a spared area (thick arrows) (Hematoxylin \& eosin, $\times 40$ for all panels).

cells, resulting in a loss of urothelium; (3) Fibroinflammatory reaction (Figure 2a and b) partially replacing the muscle of the renal pelvis. Isolated granulomas with multinucleated giant cells containing calcified material with features suggestive of calcium phosphate and calcium oxalate was noted in the pelvic wall in Cases 4 and 5 (Figure 2c). The granulomatous inflammation involved the renal pelvis diffusely (Cases 4 and 5), or focally (15$50 \%$, other cases, Figure 1d). These changes were limited to the pelvic wall (Cases 1, 2, and 3, Figure 1b) or showed focal extension to the peripelvic soft tissue (Cases 4 and 5, Figure 2a), in which only fibrosis and inflammation were observed, but there were no granulomas. The portion of the renal pelvis unaffected by granulomatous inflammation showed the types of changes usually observed in urinary obstruction, that is reactive atypia, squamous metaplasia, or nephrogenic metaplasia of the urothelium, and underlying fibro-inflammatory reaction. TammHorsfall protein was not observed in the veins or venules.

The kidneys showed focal or diffuse global glomerulosclerosis, tubular atrophy, interstitial fibrosis, and interstitial acute and chronic inflammation (Figure 4a). Focal tubulointerstitial calcification was noted in Case 2. Multifocal tubulocentric microabcesses, with or without multinucleated giant cells containing basement membrane-like material, were noted in Case 3 (Figure 4b). The ureter in each case showed mild dilation and chronic inflammation. Hilar lymph nodes available in four cases showed reactive lymphoid hyperplasia. Granulomatous inflammation was not observed in kidney, ureter, or lymph node in any case, nor was marked perinephric or peripelvic involvement or accumulation of foamy macrophages. 

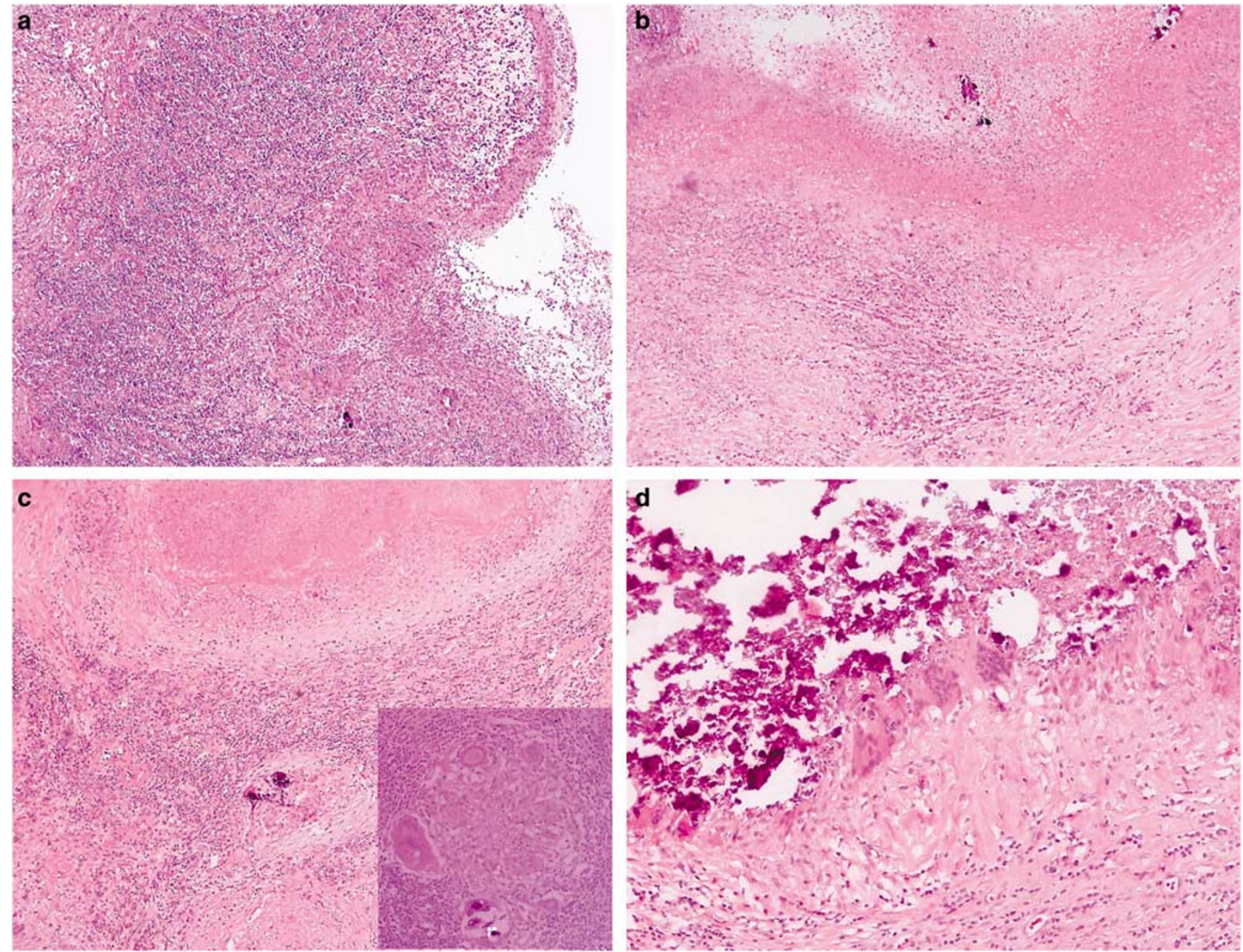

Figure 2 (a) Case 4: the granulomatous inflammation is characterized by histiocyte palisading (right) with severe inflammation in the deeper portion of the pelvic wall (left). (b) Case 5: the granulomatous inflammation includes necrotic debris, calcified material, and histiocytes, but the deeper portion of the pelvic wall shows predominantly fibrous tissue. (c) Case 4: isolated granulomas with multinucleated giant cells containing calcified material are observed deep to the pelvic granulomatous inflammation. Insert, Case 5: polarizable material consistent with calcium oxalate is seen in a multinucleated giant cell in a granuloma. (d) Case 2: granulomatous inflammation including multinucleated giant cells in response to calcified material in pelvic lumen (Hematoxylin \& eosin, $\times 100$ for (a, b, and c); $\times 400$ for (d) and the inset).

The special stains for bacteria (Gram stain), acid fast bacilli, or fungi (GMS) in each case showed no organism. Cultures taken from the renal pelvis in Cases 1, 2, and 4 were negative for aerobic bacteria, acid fast bacilli, or fungi.

\section{Discussion}

We have described in detail the clinicopathologic features of a form of chronic pyelitis chracterized by a distinctive granulomatous inflammation, which is limited to the renal pelvis and is uniformly associated with urinary obstruction. To the best of our knowledge only seven similar cases have been previously reported under the name 'pseudotuberculous pyelenephritis' as summarized in Table $1 .^{2-7}$ Although the granulomatous inflammation noted in the current and reported cases simulates tuberculosis, it is certainly not specific for this condition and further studies indeed did not showed mycobacterial infection in any of these cases. ${ }^{2-7}$ Moreover, the granulomatous inflammation is limited to the renal pelvis and spares the renal parenchyma. We therefore, wish to propose the term 'granulomatous pyelitis' as a more appropriate alternative.

The features from our five cases are in general similar to those previously reported and they together delineate Granulomatous pyelitis as a distinctive clinicopathologic entity. Granulomatous pyelitis is characterized morphologically by diffuse or focal granulomatous inflammation, which is limited to the renal pelvis and is closely associated with loss of pelvic urothelium. Various amount of necrotic, cheesy, and gritty material reminiscent of matrix stone substance was noted in the pelvic 

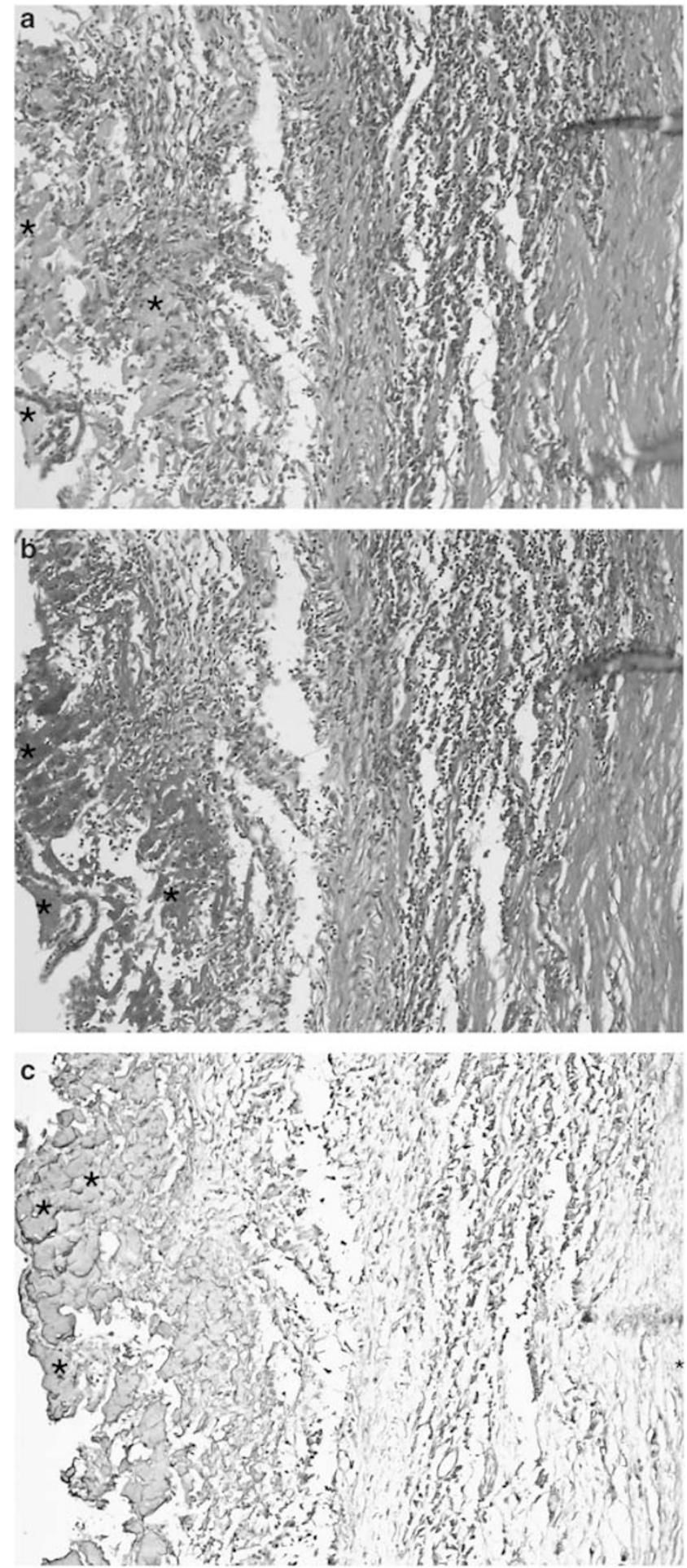

Figure 3 The pelvic granulomatous inflammation is focally associated with Tamm-Horsfall protein (asterisks) in the pelvic lumen (Case 4). This protein has a characteristic pale glassy appearance in hematoxylin \& eosin stain (a), is strongly PASpositive (b), and is positive for Tamm-Horsfall-specific antibody (c) $(\times 250$ for all panels).

lumen in each case. There was urinary obstruction concurrently or in the past, resulting in frank hydronephrosis or at least focal dilatation of the pyelocalyceal system. The urinary obstruction is almost always due to urinary tract lithiasis since renal pelvis stones with or without ureteral stones were noted in three of the five current cases and each of the seven reported cases, ${ }^{2-7}$ but other causes including ureteral stenosis are also rarely noted (current Case 1). The kidney in this condition shows chronic tubulointerstitial injury, most probably secondary to urinary obstruction, but does not show granulomatous inflammation. These features are uniformely noted in our cases and they were at least briefly described or illustrated in the reported cases. $^{2-7}$ Granulomatous pyelitis, such defined, is indeed rare since it is noted in less than $5 \%$ of cases of obstructive uropathy in our study.

The etiology of Granulomatous pyelitis is not clear. The characteristic necrotizing granulomatous inflammation raises the possibility of fungal or mycobacterial infection, but several observations conclusively negate the infectious etiology of Granulomatous pyelitis. First, Granulomatous pyelitis is almost always unilateral in conjuction with urinary tract obstruction, and the bilateral involvement in a single reported case (Case 4 in Table 1) was associated with bilateral urinary tract lithiasis and obstruction. ${ }^{5}$ Second, granulomatous inflammation is noted only in the renal pelvic wall but never in the kidney, ureter, or renal hilar lymph nodes. ${ }^{2-7}$ Third, acid fast bacili or fungi were not reported in urine, blood, or renal pelvis by special stains, cultures, or polymerase chain reaction in paraffinembefded tissue. ${ }^{2-7}$ Finally, tuberculosis or fungal infection of other organs was not seen in any case at presentation or follow-up. ${ }^{2-7}$ These contentions were illustrated well in the current Case 1 in which the patient was thought to have a history of 'cutaneous' tuberculosis 10 years previously, promoting an empirical antituberculosis treatment for a 'cystic renal lesion' detected in renal imaging. However, nephrectomy performed in response to lack of clinical improvement clearly showed features of granulomatous pyelitis, and an infectious etiology was ruled out by cultures, special stains, and follow-up.

Although the causes of the granulomatous inflammation in granulomatous pyelitis remains unclear, we wish to hypothezise that urinary tract obstruction is rarely associated with accumulation of materials in pelvis lumen or wall, which can initiate local granulomatous reaction, but not elsewhere. These materials, as observed in the current and reported cases, may include calcium, Tamm-Horsfall protein (a protein synthesized exclusively in thick Henle loops and distal tubules), necrotic cell debris, or unknown bacterial antigens, among which calcium seem to the most plausible. Several observations may support this hypothesis. The granulomatous inflammation is closely associated with calcified debris in each of the five current cases, and at least three reported cases. ${ }^{2,4,5}$ Indeed, multinucleated giant cells engulfing or closely associated with calcified material with features of either 

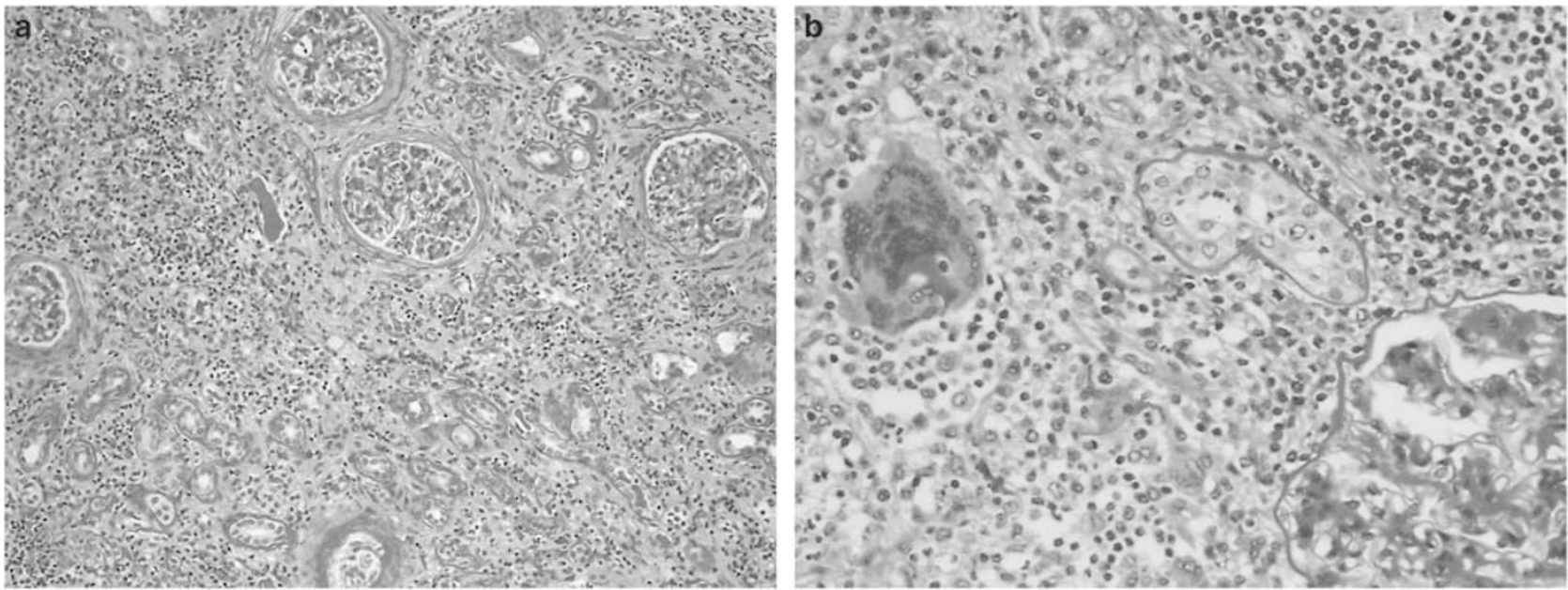

Figure 4 (a) Case 3: the kidney shows the characteristic features of chronic urinary obstruction including tubular atrophy, interstitial fibrosis, and interstitial inflammation, whereas the glomeruli are unaffected. There is no granulomatous inflammation. (b) Case 4: acute pyelonephritis is noted with severe acute and chronic inflammation of the tubulointerstitial compartment. There is a multinucleated giant cell engulfing PAS + material consistent with tubular basement membrane fragments, but granulomatous inflammation is not seen (PAS, $\times 250$ for (a) and 400 for (b)).

calcium phosphate or calcium oxalate were noted in two current cases and three reported cases. ${ }^{2,4,5}$ The accumulated calcified material in the renal pelvis may reflect both outflow obstruction and increased secretion. The increased secretion may be due hypercalciuria reported in up to $50 \%$ patients with urinary tract lithiasis, ${ }^{8}$ a condition almost always seen in those with granulomatous pyelitis. It may also reflect poor tubular reabsorption of calcium as a tubular defect associated with chronic renal failure/ end-stage renal disease, a condition seen in two current cases (Cases 1 and 2) and three reported cases. ${ }^{2,5,6}$ Localized granulomatous inflammation in response to calcium containing crystals is well known, and this condition has been reported in several organs including breast, kidney, heart, lung, skin, and ureter. ${ }^{9-14}$

Along the same line, it has been suggested that lithotripsy can cause fragmentation of the stones resulting in release of calcium-containing crystals into the renal pelvis, which trigger granulomatous inflammation. ${ }^{13}$ Lithotripsy, however, was performed in only two reported cases (Cases 3 and $5)^{4,5}$ and one of the current cases (Case 5). Whether other materials accumulated in the renal pelvic lumen, that is Tamm-Horsfall protein, necrotic cell debris, or unknown bacterial antigens, are the primary causes of GP is not clear, but each of them can potentially initiate granulomatous inflammation. $^{15}$ Although placement of stent was not described in any of the previous cases, this procedure was performed once or more than once in each of the current case 7 weeks to 12 years before nephrectomy. Whether the granulomatous inflammation is related to stent is not clear. The roles of these factors in the pathogenesis of granulomatous pyelitis would have been better understood, if their prevalences are known in cases of urinary obstruction with or without granulomatous pyelitis. These data, however, are not available from our study or literature.

Thanks to its characteristic morphology, granulomatous pyelitis can be accurately diagnosed, even without the knowledge of its clinical context, which is itself distinctive. Nevertheless, the morphologic differential diagnoses of granulomatous pyelitis may include xanthogranulomatous pyelonephritis, renal malakoplakia, granulomatous pyelonephritis of infectious etiology, granulomatous tubulointerstitial nephritis, and encrusted pyelitis. Xanthogranulomatous pyelonephritis and granulomatous pyelitis share a similar clinical background, involvement of the pyelocalyceal system, and granulomatous inflammation; however, several features characteristic for xanthogranulomatous pyelonephritis are not seen in granulomatous pyelitis, including acccumulation of foamy macrophages, inflammatory changes affecting not only the pyelocalyceal system, but also renal parenchyma, and perirenal and peripelvic soft tissue. ${ }^{16,17}$ Indeed, one current case (Case 4) was initially misdiagnosed as xanthogranulomatous pyelonephritis. Michealis-Guttman bodies, a pathognomonic feature of renal malakoplakia, are never seen in any other condition including granulomatous pyelitis; furthermore, malakoplakia usually involves the renal parenchyma rather than the renal pelvis. ${ }^{16,18,19}$ Necrotizing granulomatous inflammation and pyelocalyceal dilatation are seen in both renal tuberculosis and granulomatous pyelitis; however, renal tuberculosis is characterized by granulomatous inflammation involving predominantly the renal parenchyma, and much less frequently affecting the pyelocalyceal system; other characteristic features of renal tuberculosis including simultaneous active infection of lung or other genitourinary organs, frequent bilateral renal involvement, and positive acid fast bacilli by special stains or culture 
should be definitive. ${ }^{16}$ Fungal infection of the kidney is almost always limited to immunosuppressed patients, with renal involvement reminiscent of acute pyelonephritis rather than granulomatous inflammation; it is associated with abundant organisms detected by special stains, but prominant pyelocalyceal involvement or urinary tract obstruction is not features of renal fungal infection. ${ }^{16}$ Patients with granulomatous tubulointerstitial nephritis are usually diagnosed in the context of a medical condition requiring renal biopsy, which show granulomatous inflammation in the renal parenchyma rather than involvement of the pyelocalyceal system. ${ }^{20,21}$ Encrusted pyelitis is rare condition characterized by marked tissue deposition of calcium-containing material, associated with severe necrotic debris and predominantly acute inflammation. ${ }^{22,23}$ It is due to infection with urea splitting bacteria, especially Corynebacterium urealyticum, which alkalize urine and thus facilitate tissue deposition of calcium salts. This condition, which is much more common in the bladder than in renal pelvis, usually develops against the background of chronic immuno-suppression including organ transplant, or previous infection or instrumentation of the urinary tract. Although cultures for urea splitting bacteria was not performed in the current cases of granulomatous pyelitis, this condition can be clearly differentiated from encrusted pyelitis since the granulomatous inflammation with tissue zonation characteristic for granulomatous pyelitis has not been described in encrusted pyelitis. Furthermore, although calcium deposition is frequent in GP, it is focal and not as extensive as in encrusted pyelitis. Finally, the different medical backgrounds of these two conditions also help with the differential diagnosis'

In summary, granulomatous pyelitis is a rare clinicopathologic entity characterized by granulomatous inflammation limited to the renal pelvis, which is uniformly associated with urinary tract obstruction and pyelocalyceal dilatation and may develop in response to accumulated calcified material in the renal pelvis. Awareness of this entity and its characteristic clinicopathologic features also helps eliminate an infectious etiology with obvious treatment and prognostic implications.

\section{References}

1 Heptinstall RH. Urinary Tract Infection, Pyelonephritis, Reflux Nephropathy. In: Jennette JC, Olson JL, Schwartz MM, Silva FG (eds). Hepstinstall's Pathology of the Kidney, 5th edn. Lippincott-Raven: Philadelphia-New York, 1998, p 725.

2 Hoorens A, Van Der Niepen P, Keuppens F, et al. Pseudotuberculous pyelonephritis associated with nephrolithiasis. Am J Surg Pathol 1992;16:522-525.
3 Valerdiz Casasola S, Parra ML, Garcia AJ. Pseudo-tuberculous pyelonephritis. Arch Esp Urol 1994;47:172-174.

4 Bouzourene H, Bouzourene N, Francke ML. An unusual granulomatous form of chronic pyelonephritis mimicking tuberculosis. Histopathology 1998;35: 481-482.

5 Muldoon C, Hickey D, Murphy D, et al. Pseudotuberculous pyelonephritis: a rare entity and a diagnostic pitfall. Histopathology 1999;35:181-183.

6 Kim SW, Yeum CH, Nah MY, et al. Pseudotuberculous pyelonephritis in a patient with autosomal dominant polycystic kidney disease undergoing long-term haemodialysis. Nephrol Dial Transplant 2001;16: 1729-1730.

7 Ikeda D, Fukuda M, Takashima H, et al. Pseudotuberculous pyelonephritis associated with staghorn calculus: a case report. Nippon Hinyokika Gakkai Zasshi 2003;94:29-32.

8 Lemann Jr J, Gray RW. Idiopathic hypercalciuria. J Urol 1989;141:715-719.

9 Edmundo J, Gonzalez G, Caldwell RG, et al. Calcium oxalate crystals in the breast: pathology and significance. Am J Surg Pathol 1991;15:586-591.

10 Lewis RD, Lowenstam HA, Rossman GR. Oxalate nephrosis and crystalline myocarditis: case report with postmortem and crystallographic studies. Arch Pathol 1974;98:149-155.

11 Visscher D, Churg A, Katzenstein AL. Significance of crystalline inclusions in lung granulomas. Mod Pathol 1988;1:415-419.

12 Swinehart JM, Golitz LE. Scrotal calcinosis. Dystrophic calcification of epidermoid cysts. Arch Dermatol 1982;118:985-988.

13 Dretler SP, Young RH. Stone granuloma: a cause of ureteral stricture. J Urol 1993;150:1800-1802.

14 Bischel MD, Abrams BL, Goldfarb I, et al. Granulomatous interstitial nephritis complicating jejunoileal bypass. Arch Pathol Lab Med 1980;104:112-113.

15 Shikama Y, Kobayashi K, Kasahara K, et al. Granuloma formation by artificial microparticles in vitro. Macrophages and monokines play a critical role in granuloma formation. Am J Pathol 1989;134:1189-1199.

16 Chuang CK, Lai MK, Chang PL. Xanthogranulomatous pyelonephritis: experience in 36 cases. J Urol 1992; 147:33-40.

17 Seshan SV, D’Agati VD, Appel GA, et al. Renal Disease: Classification Atlas of Tubulointerstitial and Vascular Diseases. Williams \& Wilkins: Baltimore, 1999.

18 Dobyan DC, Truong LD, Eknoyan G. Renal malakoplakia reappraised. Am J Kidney Dis 1993;23:243-246.

19 Esparza AR, McKay DB, Cronan JJ. Renal parenchymal malakoplakia. Histologic spectrum and its relationship to megalocytic interstitial nephritis and xanthogranulomatous pyelonephritis. Am J Surg Pathol 1989;13: 225-236.

20 Viero RM, Cavallo T. Granulomatous interstitial nephritis. Hum Pathol 1995;26:1347-1353.

21 Nasr SH, Koscica J, Markowitz GS, et al. Granulomatous interstitial nephritis. Am J Kidney Dis 2003;41: 714-719.

22 Morales JM, Aguado JM, Diaz-Gonzalez R, et al. Alkaline-encrusted pyelitis/cystitis and urinary tract infection due to Corynebacterium urealyticum: a new severe complication after renal transplantation. Transplant Proc 1992;24:81-82.

23 van Hooland S, Vandooran AK, Lerut E, et al. Alkaline encrusted pyelitis. Acta Clin Belg 2005;60:369-372. 